\title{
ESCANEAMENTO 3D A LASER, FOTOGRAMETRIA E MODELAGEM DA INFORMAÇÃO DA CONSTRUÇÃO PARA GESTÃO E OPERAÇÃO DE EDIFICAÇÕES HISTÓRICAS ${ }^{1}$
}

\author{
3D LASER SCANNER, PHOTOGRAMMETRY AND BIM FOR HISTORIC \\ BUILDINGS FACILITIES MANAGEMENT AND OPERATION
}

\author{
Eloisa Dezen-Kempter \\ Universidade Estadual de Campinas (UNICAMP) \\ elo@ft.unicamp.br \\ Lúcio Soibelman \\ University of Southern California (USC) \\ soibelman@usc.edu \\ Meida Chen \\ University of Southern California (USC) \\ meidache@usc.edu \\ Alexandre Victor Müller Filho, \\ Universidade Federal de Santa Catarina (UFSC) \\ alexandremullerfilho@gmail.com
}

\begin{abstract}
Resumo
Este artigo apresenta os resultados de integração de tecnologias de levantamento híbridas (escaneamento 3D a laser, fotogrametria) para a captura do estado real de uma edificação histórica do Campus da University of Southern California em Los Angeles visando a sua modelagem BIM. O estudo de caso é um edifício de dois andares, construído em 1964 em linguagem modernista, com estrutura metálica aparente, considerado patrimônio histórico recentemente. A escolha da abordagem híbrida pautou-se em critérios como: precisão dos dados levantados; nível de detalhe requerido para cada elemento do edifício; esforço para aquisição e pósprocessamento dos dados; e acessibilidade ao elemento a ser capturado. Levando-se em conta os resultados obtidos, apresentamos a avaliação das ferramentas e estratégias empregadas para aquisição dos dados espaciais do edifício, em função dos seguintes critérios: escala, complexidade e alcance dos equipamentos. $O$ modelo tridimensional em forma de nuvens de pontos gerado pela captura constitui a base para a criação de um modelo de informações de construção semanticamente orientado, ferramenta potencial para produzir um inventário abrangente que considere os requisitos de manutenção peculiares de edificações históricas. Esse artigo pretende contribuir para ampliar a discussão sobre a adoção de BIM na área de patrimônio histórico.
\end{abstract}

Palavras-chave: BIM. Gestão e Operação. Patrimônio Histórico. 3D laser scanner. Fotogrametria.

\footnotetext{
1 DEZEN-KEMPTER, E.; SOIBELMAN, L.; CHEN, M.; MÜLLER, A.V. Escaneamento 3D a laser, fotogrametria e modelagem da informação da construção para gestão e operação de edificações históricas. In: ENCONTRO BRASILEIRO DE TECNOLOGIA DE INFORMAÇÃO E COMUNICAÇÃO NA CONSTRUÇÃO, 7., 2015 , Recife. Anais... Porto Alegre: ANTAC, 2015.
} 


\begin{abstract}
This article presents the results of integrating hybrid-surveying technologies (3D laser scanning, Photogrammetry) to capture the real state of a historic building on the campus of the University of Southern California in Los Angeles aiming to create its BIM model. The case study is a two-story building, built in 1964 in modernist language, with apparent steel structure, considered historical heritage recently. The adoption of hybrid approach was guided on the following criteria: accuracy of data collected; level of detail required for each element of the building; effort to acquire and post-processing of data; and accessibility to the element to be captured. Taking into account the results obtained, we present the evaluation of the tools and strategies used to acquire the building's spatial data, according to the following criteria: scale, complexity and range of equipment. The point clouds threedimensional model, generated by the capturing tools, forms the basis for creating a semantically oriented building information model. BIM is a potential tool to produce a comprehensive inventory that considers the unique maintenance requirements of historic buildings. This article intends to contribute to the discussion on the adoption of BIM in the heritage area.
\end{abstract}

Keywords: BIM. Facilities Management. Historic Heritage. 3D laser scanner. Photogrammetry.

DOI: http://dx.doi.org/10.11606/gtp.v10i2.102710 